\title{
Healthy housing: A case study of intersectoral collaboration for better health
}

\author{
Behzad Damari ${ }^{1}$, Kamel Shadpour ${ }^{2}$, Narges Roostamigooran ${ }^{3 *}$ \\ Received: 27 Mar 2017 \\ Published: 30 July 2018
}

\begin{abstract}
Residency areas are primary social factors that directly and indirectly affect health and in synergy with other factors, changes health equity indices.

Qazvin as one of the provinces in the Islamic Republic of Iran has been a pioneer in the provision of an integrated health program with intersectoral collaboration approach and the participation of residents.

In this study required data was gathered in a qualitative method by reviewing documents, group discussions with stakeholders and residents and interviews with key informed individuals. In the beginning, stakeholder's analysis revealed highly effective organizations and their method of cooperation.

Insufficient access to housing, weak security, insufficient swage system and deficiency of entertainment and park environment are four top urgent issues which are related to housing. Strategic goals for each issue has been designed in a four-year time frame and projects for reaching the goals that are considered in three categories: promotional, facilitator and mandatory.

Cooperation of multiple stakeholders including managers and residents are features of preparing this program. A change of stakeholders' perspective to health-oriented performance in housing is the added value of this public act.
\end{abstract}

Keywords: Housing, Intersectoral collaboration, Social determinant of health

Copyright $\bigcirc$ Iran University of Medical Sciences

Cite this article as: Damari B, Shadpour K, Roostamigooran N. Healthy housing: A case study of intersectoral collaboration for better health. Med J Islam Repub Iran. 2018(30 July);32:64. https://doi.org/10.14196/mjiri.32.64

Unfair distribution of health outcomes is not only the product of insufficient health care and treatment systems, but is mainly the result of circumstances in which people are born, grow up, work, live and age. Thus, the three basic principles for reducing injustices related to health are: improving daily life circumstances, opposing unfair distribution of power, money and resources, evaluating injustices related to health and evaluating the remedial actions/measures (1).

Housing and the surrounding environment are the basic requirements of survival and lay a foundation for individ-

Corresponding author: Dr Narges Roostamigooran, rostamigooran@yahoo.com

1. Neuroscience Institute, Tehran University of Medical Science, Tehran, Iran.

2. Ministry of Health and Medical Sciences, Tehran, Iran. [Passed away on 2014]

3. Ministry of Health and Medical Sciences, Secretariat of Supreme Council of Health and Food Security, Tehran, Iran. uals to take care of their other basic needs. A suitable house means shelter of fair price, secure and safe for everyone. The absence of this type of shelter, high real estate costs, lack of security, unsuitable quarter, defected design of housing and its equipment are the aspects which are influencing physical, mental and social health in many different ways (2).

Housing and residential areas are also related to the other social determinants of health such as childhood development. Children who live in a healthy environment and gain access to educational and entertainment facilities and

$\uparrow$ What is "already known" in this topic:

As a social determinant of health intervention for better housing, we need intersectoral collaboration and public participation which are triggered and supported by health sector to reach a common view about priorities of interventions.

\section{$\rightarrow$ What this article adds:}

It is possible to form a workgroup including representatives from civil society and governmental organizations at the provincial level for dealing with public health problems such as housing and residential environment. From the common view of directors, technical officers and civil society, housing supply intervention and housing quality promotion intervention in terms of health and safety, are necessary for healthy housing. 
safety, thrive better (3).

Policies and regulations about housing and urbanization or citizens' rights can directly or indirectly affect the health of residents. Therefore, designing and evaluating the effectiveness of interventions in housing and considering other social factors, especially poverty and deprivation are issues in studying the relationship between health and housing.

This study is a part of "integrated health program" which was piloted in Qazvin province with the goals of improvement in health and health equity indices in Qazvin.

The aim of the study is to prepare situational analysis report and determine provincial interventions to improve housing facilities and residential areas. Required data was gathered in a qualitative method by reviewing documents, group discussions with stakeholders and residents and interviews with key informed individuals. In the beginning, stakeholder analysis revealed the highly effective organizations and their method of cooperation.

Through stakeholder analysis, provincial intersectoral committee in housing was formed. Other necessary members were selected with snowball method (at least 10 members) for attending meetings and in-depth interviews.

The provincial intersectoral committee was trained through three methods:

1. Training workshops for planning principles and programming, problem-solving and choosing interventions and providing a training manual for planning.

2. Using facilitators and consultants familiar with the methodology (in meetings, via telephone and e-mail)

3. Providing training pamphlets about scientific evidence of housing and health.

Then the committee prioritized problems based on 5 cri- terion including: the basic need of province, more impact on people's health, dissolved within 5 years, effectiveness of early and activities lead to achieve 2025 goals. The next step was to analyze and discover the cause of $20 \%$ of the first listed problems. The chosen cases were categorized based on result chains regarding "the level of the problem" as input, process, output, outcome, and effect .For finding the reason of the problem, triangle pattern was used. The reason of each problem was categorized based on committee member's comments and using available indices of in three fields of; legal -political, structural operational and behavioral- cultural. Strategic goals were determined by members of the working group after reviewing the chain of problems in a way that the problem could be solved within 5 years. After setting strategic goals and considering opportunities in the province, for each strategic goal three projects and the necessary financial resources were determined.

Qazvin covers an area of $15570 \mathrm{~km}^{2}$ and holds a population of 1201565 people (2011 capitation) which contributes to $16 \%$ of Iran's population. About $73 \%$ of the inhabits in urban areas and $84 \%$ are literate (4-5). Housing share of household expenses in 2013 was estimated 16.37 (6). Other housing indices in Iran in 2013 are depicted in Table 1.

In this program and in the housing field, lack of housing availability, unsuitable house safety, incomplete sewage system and shortage of entertainment area and parks have been the top challenges in housing and residential areas. Goals are set to reach each issue in a 5 years' vision determined as below:

- Providing housing for $40 \%$ of deprived/underserved citizens

- Increasing secure, resistant and comfortable housing

Table 1. Housing indices in Qazvin in 2013

\begin{tabular}{cccc}
\hline $\begin{array}{c}\text { Urban green space } \\
\text { per capita }\end{array}$ & $\begin{array}{c}\text { Mean of substructure land } \\
\text { of built residential units in } \\
2013\end{array}$ & $\begin{array}{c}\text { Mean of the rent a residential } \\
\text { unit }\left(10^{3} \text { rials }\right)\end{array}$ & $\begin{array}{c}\text { Mean price of } 1 \mathrm{~m}^{2} \\
\text { residential land for rede- } \\
\text { velopment }\left(10^{3} \text { rials }\right)\end{array}$ \\
\hline $12.04 \mathrm{~m}^{2}$ & $133 \mathrm{~m}^{2}$ & 55503 & 4069 \\
\hline
\end{tabular}

Table 2. Strategic goals and defined projects to improve housing

\begin{tabular}{|c|c|c|}
\hline & Goals & Projects \\
\hline 1 & $\begin{array}{l}\text { Providing housing for } 40 \% \\
\text { of deprived/underserved } \\
\text { citizens }\end{array}$ & $\begin{array}{l}\text { - Studying and constructing a sample of cheap, secure, comfortable house which is suitable for the area } \\
\text { climate } \\
\text { - Estimating the cost of providing house for } 20 \% \text { of people with no house and providing it with the help of } \\
\text { banks, government services and charities. } \\
\text { - Supervising the process of providing housing for } 10 \% \text { of deprived citizens }\end{array}$ \\
\hline 2 & $\begin{array}{l}\text { Increasing secure, resistant } \\
\text { and comfortable housing by } \\
30 \% \text { in urban and rural areas } \\
\text { and reducing special events } \\
\text { related to insecure housing } \\
\text { by } 50 \%\end{array}$ & $\begin{array}{l}\text { - Preparing and communicating a by-law for supervising security and comfort of housing } \\
\text { - Evaluating resistance, security and convenience of housing } \\
\text { - Designing educational packages for secure and healthy homes } \\
\text { - Implementing educational programs of secure, healthy homes via media } \\
\text { - training and organizing building workers } \\
\text { - Approve and implement accrediting by-laws for the province building contractors }\end{array}$ \\
\hline 3 & $\begin{array}{l}\text { Equipping Qazvin to urban } \\
\text { sewage system and } 20 \% \text { of } \\
\text { villages with more than } 150 \\
\text { population }\end{array}$ & $\begin{array}{l}\text { - Feasibility study project for creating urban sewage system (including international and national experienc- } \\
\text { es, finances, timing and barriers of support, estimations to provide financial resources, recall and choosing } \\
\text { contractor and supervisor. } \\
\text { - Providing sewage system for villages with more than } 150 \text { population } \\
\text { - Preparing an integrated program for natural sewage in rural areas }\end{array}$ \\
\hline 4 & $\begin{array}{l}\text { Fairly distribute safe sport } \\
\text { and entertainment areas in } \\
\text { each urban and rural district } \\
\text { as twofold of the existing } \\
\text { areas - } 30 \% \text { increase in the } \\
\text { existing entertainments. }\end{array}$ & $\begin{array}{l}\text { - Creating an information bank for tourism and entertainment sites } \\
\text { - Designing a model for entertainment and sport centers and determining a method and costs of setting it up } \\
\text { - Creating a designed model for entertainment sport centers in } 24 \text { cities and } 46 \text { villages } \\
\text { - Finding locations for setting up parks and setting standards for them } \\
\text { - Preparing, informing and supervising on by-laws for reducing taxes and levies to build entertainment sport } \\
\text { centers (recreation centers) }\end{array}$ \\
\hline
\end{tabular}


by $30 \%$ in urban and rural areas and reducing special events related to insecure housing by $50 \%$

- Equipping Qazvin to urban sewage system in $20 \%$ of villages with more than 150 population

- Increasing and fairly distributing safe sport and entertainment areas in each city and rural district to two-fold and $30 \%$ increase in the existing entertainments.

In order to achieve each of the above goals, some projects have been defined as shown in Table 2 .

In general, an intervention that has used budget friendly, effective and long-lasting technologies has been more successful, specifically if it includes educational and behavioral interventions. Interventions based on social determinants of health which are considered other effective factors on health like earning, employment and training and interventions which covers all family members especially children, comes with more success (7).

Generally, suggested intervention by housing and urban area working group can be divided into two groups:

\section{Housing supply intervention \\ Owning a house}

In one of the strategic programs in Canada, suggestions and solutions to lessen homeless conditions are as: Increasing the number of cheap houses and residential loans for youth and endangered people, providing consultancy and guidelines to endangered people to use supportive loans and creating housing database and observation on demand and supply of housing, increasing communication between stakeholders and related organizations and a general support of groups with homeless risks, increasing temporary housing areas and promoting the accessibility of homeless people to homes (8).

In Qazvin General Health Program, the most important solution is to raise finance for vulnerable population and monitoring the social support providing to these individuals, and expected at the end of the program 40 percent of families that were vulnerable and homeless became capable of owning a house. There is no doubt that this goal is not reachable with the sole financial support of governmental entities and charities, other actions and poverty-fighting programs must be undertaken for decreasing vulnerable population. Reducing unemployment rate to 2 percent and increasing preventive measures on social harms about $50 \%$ were the main purposes for decreasing poverty level which were considered in two other workgroups (employment workgroup and social supports workgroup) (9).

\section{Housing quality promotion intervention in terms of health and safety}

Unsuitable living places have direct relation with communicable diseases like infections and increase in the risk of acquiring non- communicable diseases $(10,11,12)$ Systematic reviews show that housing status improvement is related to physical health enhancement especially respiratory system disease and their symptoms, psychological health and even the improvement of social health factors like no sense of isolation, better relationship with neigh- bors and increasing the sense of safety and lessen the fear of crime and generally contentment on living places (4, 13).

In Qazvin general health program, most actions were taken on structural improvement, considering the point that the city is located on the earthquake line and has old building tissues.

Thus improvement of housing condition and residential spaces can be effective in two ways on health and health equity indices in health frameworks. In the direct method, with reducing risk factors, communicative and noncommunicative diseases are reduced and in the indirect method, living area improvement includes a better social class for an individual and reduces the stresses. Therefore, it finally causes an improvement in psychological and physical status of residents. To gain success in future, it is recommended that housing improvement planning to be included in poverty reduction policies. Increasing employment plans and enhancing people's knowledge about better housing should be considered as well.

\section{Acknowledgments}

This study was funded by Qazvin University of Medical Science, Islamic Republic of Iran. Governor-general of Qazvin and Ministry of Health and Medical Education have supported it by technical assistance and advisorship.

\section{Conflict of Interests}

The authors declare that they have no competing interests.

\section{References}

1. Commission On Social Determinants Of Health Knowledge. Closing the gap in a generation: health equity through action on the social determinants of health. Final Report of the Commission on Social Determinants of Health. 2008, Geneva, World Health Organization.

2. Southern Public Health Unit Network. Social Determinants of Health Housing Fact Sheet. West Moreton Public Health Unit, Ipswich. Available from: http://citeseerx.ist.psu.edu/viewdoc/download?

3. Niki M . Housing as a Social Determinant of Health Policy Brief prepared for the Middle Childhood Initiative of the National Children's Alliance, 2006: 1-6.

4. Office of Statistics and Information. Data Center .Selective economic,social and cultural indicators of Ghazvin proviance in 2013, Ghazvin, 2013.

5. http://www.amar.org.ir/Default.aspx?tabid=1678 retrived at 2015/ $20 / 4$

6. Abegunde DO, Mathers CD, Adam T, Ortegon M, Strong K. The burden and costs of chronic diseases in low -income and middleincome countries. The Lancet, 2007; 370: 1939-1946

7. Saegert SC, Klitzman S, Freudenberg N, Cooperman-Mroczek J, Nassar S. Healthy Housing: A Structured Review of Published Evaluations of US Interventions to Improve Health by Modifying Housing in the United States, 1990-2001. Am J Public Health, 2003; 93(9): 1471-1477.

8. Nosbush LL. Community action plan on homelessness and housing. 2007, Community Service Department: Prince Alberta. p. 65-71.

9. Shadpour K. Primary health care networks in the Islamic Republic of Iran. East Mediterr Health J. 2000;6(4):822-825.

10. Corburn J. Reconnecting with our roots. American urban planning and public health in the twenty-first century. Urban Aff Rev. 2007; 42:688-713

11. Vijayaraghavan M, Kushel MB, Vittinghoff E, Kertesz S, Jacobs D, Lewis CE, Sidney S, Bibbins-Domingo K. Housing instability and incident hypertension in the CARDIA cohort. J Urban Health. 2013;90(3):427-41. 
Healthy housing

12. Matte TD, Jacobs DE. Housing and health--current issues and implications for research and programs. J Urban Health. 2000;77(1):7-25.

13. Thomson H, Atkinson R, Petticrew M, Kearns A. Do urban regeneration programmes improve health and reducehealth inequalities? A synthesis of the evidence from UK policy and practice (1980-2004). J Epidemiol Community Health. 2006;60:108-115. 